CLINICAL STUDY

\title{
The diagnosis of GH deficiency in obese patients: a reappraisal with GHRH plus arginine testing after pharmacological blockade of lipolysis
}

\author{
Massimo Scacchi, Federica Orsini, Agnese Cattaneo, Alice Grasso, Barbara Filippini, Francesca Pecori Giraldi, \\ Letizia Maria Fatti, Mirella Moro and Francesco Cavagnini \\ Division of Endocrinology and Metabolic Diseases, Cattedra di Endocrinologia, Università degli Studi di Milano, Ospedale San Luca IRCCS, Istituto \\ Auxologico Italiano, Via Spagnoletto 3, 20149 Milano, Italy \\ (Correspondence should be addressed to F Cavagnini; Email: cavagnini@auxologico.it)
}

\begin{abstract}
Background: The diagnosis of GH deficiency (GHD) in obese patients is complicated by the reduced GH secretion associated with overweight. A GH response to GHRH+arginine lower than $4.2 \mu \mathrm{g} / \mathrm{l}$ is currently considered indicative of GHD in obesity. The aim of the study was to investigate the effect of acute pharmacological blockade of lipolysis on the GH response to GHRH + arginine in obese patients. Patients and methods: Two groups of patients were studied: 12 obese patients with proven GHD and 14 patients with essential obesity. On separate occasions, two tests were carried out in each patient: GHRH + arginine and GHRH + arginine preceded by acipimox.

Results: The mean GH peak after GHRH + arginine was significantly lower in hypopituitary patients than in subjects with essential obesity. Acipimox significantly increased the mean GH response in patients with essential obesity, but not in hypopituitary subjects. All hypopituitary patients and 7/14 patients with essential obesity displayed GH peaks lower than $4.2 \mu \mathrm{g} / \mathrm{l}$ after GHRH + arginine: the GH response to the test increased after acipimox pretreatment in five of these seven essentially obese subjects. After acipimox administration, free fatty acids (FFAs) significantly fell in both groups with comparable mean absolute decreases. All IGF1 values were normal in both groups of subjects.

Conclusions: Our study has demonstrated that the acipimox-induced acute reduction of circulating FFA levels increases mean somatotropin response to GHRH+arginine in patients with essential obesity, whereas it has no effect in hypopituitary subjects. The current criterion for the diagnosis of GHD in obese patients may be misleading. Indeed, subjects affected by third degree obesity, like most of our patients, may be erroneously classified as really GH-deficient and started on an expensive unjustified treatment. It appears therefore that the current criteria for the diagnosis of GHD in obesity should be reconsidered in the light of further studies also taking into account different body mass index groups.
\end{abstract}

European Journal of Endocrinology 163 201-206

\section{Introduction}

GH deficiency (GHD) syndrome in adults is characterized by abnormal body composition (visceral adiposity, reduced muscle mass, and decreased bone mineral density), atherogenic lipid profile, impaired physical performance and quality of life, and reduced life expectancy $(1,2)$. Such clinical and metabolic derangements improve during recombinant human $\mathrm{GH}$ therapy $(3,4)$.

Based on a clinical suspicion, GHD must be confirmed by the assessment of GH secretion performed using pharmacological challenges such as insulin tolerance test (ITT) or GHRH + arginine. The latter is currently considered the favorite diagnostic tool due to its high specificity and sensitivity, as well as tolerability (5). Adipose tissue represents a major negative determinant of somatotropin secretion (6), and indeed obesity is characterized by profound impairment of spontaneous and stimulated GH release. As a consequence, obese subjects may display GH responses to provocative tests overlapping those of patients with severe GHD (7). Thus, obesity represents the most important confounding factor in the diagnosis of GHD.

Two Italian studies $(8,9)$ have recently addressed this issue investigating large groups of hypopituitary patients and establishing body mass index (BMI)-related cut-off values for the somatotropin response to GHRH+ arginine by percentile analysis and receiver-operating characteristic curves. In particular, GH cut-offs for the diagnosis of severe GHD in adults with BMI $>30 \mathrm{~kg} / \mathrm{m}^{2}$ were $4.2 \mu \mathrm{g} / \mathrm{l}$ in the experience of Corneli et al. (8) and $5.5 \mu \mathrm{g} / \mathrm{l}$ in the hands of Colao et al. (9) respectively. Indeed, GH response lower than $4 \mu \mathrm{g} / \mathrm{l}$ is considered 
diagnostic for severe GHD in obese patients by the recently revised guidelines of several scientific societies (GH Research Society, European Society for Pediatric Endocrinology, Lawson Wilkins Society, European Society of Endocrinology, Japan Endocrine Society, and Endocrine Society of Australia) (10).

Several lines of experimental evidence indicate that high circulating free fatty acids (FFAs) play an important role in the impairment of spontaneous and stimulated GH secretion in obesity, given the improvement of somatotropin release observed in obese patients after the administration of the antilipolytic agent acipimox (11).

Based on the above, we performed a study aimed at investigating the influence of acute pharmacological blockade of lipolysis on the $\mathrm{GH}$ response to GHRH + arginine in obese patients with proven GHD and in subjects classified as having essential obesity.

\section{Patients and methods}

\section{Patients}

Two groups of patients were studied: i) 12 obese patients with proven GHD (6 men and 6 women, mean age $53.1 \pm 17.36$ years) due to diseases of the hypothalamic-pituitary region and/or to their treatment (see Table 1 for details); ii) 14 patients classified as having essential obesity ( 4 men and 10 women, mean age $49.9 \pm 16.83$ years). Mean BMI was significantly higher in essentially obese subjects than in GHD patients $\left(44.2 \pm 5.73\right.$ vs $\left.38.7 \pm 5.45 \mathrm{~kg} / \mathrm{m}^{2}, P<0.05\right)$. Hypopituitary patients were studied before the instatement of biosynthetic GH therapy; hormone deficiencies other than GHD were treated with adequate replacement therapy, i.e. levothyroxine (Eutirox, Bracco SpA, Milan, Italy), cortisone acetate (Cortone, Istituto Chimico Internazionale Rende, Rome, Italy), and testosterone enanthate (Testo Enant, Geymonat SpA, Anagni, Italy) in men, and oestrogen-progestogen association in women, desmopressin (Minirin DDAVP, Ferring), as appropriate. At the time of the study, none of the patients suffered from diseases known to affect GH-insulin-like growth factor 1 (IGF1) secretion, such as diabetes mellitus, chronic renal failure, and liver insufficiency. All patients gave their informed consent to participate in the study, which was approved by the Ethics Committee of our Institution.

\section{Test procedures}

On separate occasions and in random order, two tests were carried out for each patient: GHRH + arginine and GHRH + arginine preceded by acipimox (Olbetam $250 \mathrm{mg}$, Pfizer Italia srl), orally, at -270 and $-60 \mathrm{~min}$.

On both occasions, an indwelling catheter was placed into a forearm vein and continuously flushed with saline. Two baseline samples were collected prior to injection of $1 \mu \mathrm{g} / \mathrm{kg}$ body weight GHRH (Geref, Serono) as an i.v. bolus and infusion of $0.5 \mathrm{~g} / \mathrm{kg}$ body weight (maximal dose $30 \mathrm{~g}$ ) arginine (S.A.L.F., Turin, Italy) over $30 \mathrm{~min}$ through a separate i.v. access. Blood samples were then collected at $15,30,45,60$, and 90 min after the beginning of the infusion. Blood samples were centrifuged at $1000 \boldsymbol{g}$ for $10 \mathrm{~min}$ at $4{ }^{\circ} \mathrm{C}$; serum was collected by aspiration and stored at $-20{ }^{\circ} \mathrm{C}$ until assayed for GH. IGF1, FFA, and insulin concentrations were measured in serum samples collected at baseline.

\section{Biochemical assays}

Serum GH concentrations were measured by chemiluminescent assay (CLIA, Nichols Institute Diagnostics, San Juan Capistrano, CA, USA). Intra-assay coefficients of variation $(\mathrm{CV})$ for mean $\mathrm{GH}$ levels of $0.8,5.9$, and $17.1 \mu \mathrm{g} / \mathrm{l}$ were $2.8,3.7$, and $5.4 \%$ respectively. Inter-assay $\mathrm{CV}$ for mean $\mathrm{GH}$ levels of $0.1,6.2$, and $16.2 \mu \mathrm{g} / \mathrm{l}$ were $7.5,6.2$, and $8.7 \%$ respectively. The sensitivity of the assay is $0.02 \mu \mathrm{g} / \mathrm{l}$. The assay was calibrated against the IS 98/574 recombinant standard.

IGF1 serum concentrations were determined by CLIA (Nichols Institute Diagnostics) after IGF1

Table 1 Demographics and etiology of GH deficiency (GHD) in hypopituitary patients.

\begin{tabular}{|c|c|c|c|c|}
\hline Patient & Gender & Age (years) & BMI $\left(\mathrm{kg} / \mathrm{m}^{2}\right)$ & Hypothalamic-pituitary disease \\
\hline 1 & $\mathrm{~F}$ & 68 & 30.5 & Panhypopituitarism after surgical removal of a non-functioning pituitary macroadenoma \\
\hline 2 & $\mathrm{~F}$ & 55 & 41.4 & $\begin{array}{l}\text { Panhypopituitarism after surgical removal and radiotherapy for a non-functioning pituitary } \\
\text { macroadenoma }\end{array}$ \\
\hline 3 & $\mathrm{~F}$ & 36 & 38.5 & Persistent GHD after transsphenoidal surgery for Cushing's disease \\
\hline 4 & $\mathrm{~F}$ & 63 & 33.8 & Partial hypopituitarism in empty sella \\
\hline 5 & $\mathrm{~F}$ & 51 & 36.1 & Idiopathic GHD \\
\hline 7 & M & 48 & 35.3 & Partial hypopituitarism in empty sella \\
\hline 8 & M & 27 & 32.0 & Persistent GHD after transsphenoidal surgery for Cushing's disease \\
\hline 9 & M & 67 & 42.5 & Partial hypopituitarism following spontaneous apoplexy of pituitary macroadenoma \\
\hline 10 & M & 75 & 46.5 & Partial hypopituitarism following spontaneous apoplexy of pituitary macroadenoma \\
\hline 11 & M & 36 & 40.5 & Partial hypopituitarism due to sellar germinoma \\
\hline 12 & M & 33 & 39.0 & Panhypopituitarism after surgical removal of a craniopharyngioma \\
\hline
\end{tabular}


separation from IGF-binding proteins by sample acidification. Intra-assay CV for mean IGF1 levels of 63, 208 , and $766 \mu \mathrm{g} / \mathrm{l}$ were $4.8,5.2$, and $4.4 \%$ respectively. Inter-assay CV for mean IGF1 levels of 62, 215, and $811 \mu \mathrm{g} / \mathrm{l}$ were $7.1,5.7$, and $7.4 \%$ respectively. Assay sensitivity is $6 \mu \mathrm{g} / \mathrm{l}$. Data are expressed as IGF1 SDS values, calculated according to Brabant et al. (12). IGF1 SDS was used as a variable in all statistical analyses involving IGF1. IGF1 SDS values less than -1.88 (third percentile) were considered abnormally low.

Serum FFA concentrations were determined by RANDOX colorimetric method.

Serum insulin concentrations were measured by electrochemiluminescent immunoassay (ECLIA, Roche Diagnostics $\mathrm{GmbH}$ ). Intra- and inter-assay $\mathrm{CV}$ were 2.6 and $4.9 \%$ respectively. Assay sensitivity is $0.2 \mathrm{mU} / \mathrm{l}$. The reference range is $2.6-24.9 \mathrm{mU} / \mathrm{l}$.

\section{Statistical analysis}

Results are presented as mean \pm s.D. KolmogorovSmirnov test was used to establish normality, and Student's $t$-test for unpaired or paired data was used for inter- and intra-group comparisons respectively. Linear regression analysis was used to evaluate associations between variables. Statistical analyses were performed with commercially available software packages (Statview, Abacus Concepts, Berkeley, CA, USA; MedCalc Software, Mariakerke, Belgium). A P value $<0.05$ was considered statistically significant.

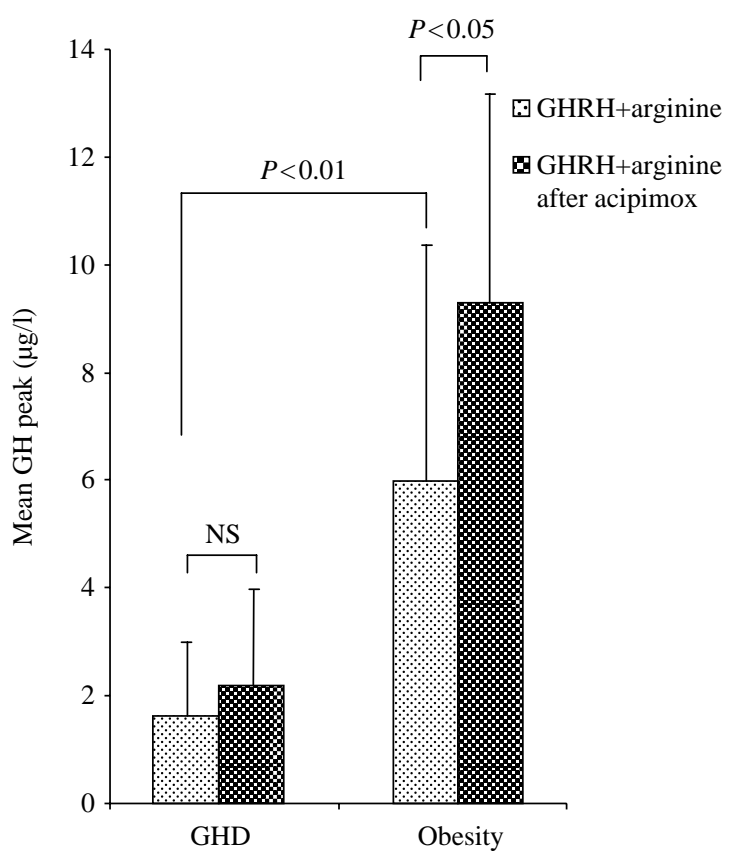

Figure 1 Mean GH peak after GHRH + arginine with and without acipimox pretreatment in patients affected by GHD or obesity.

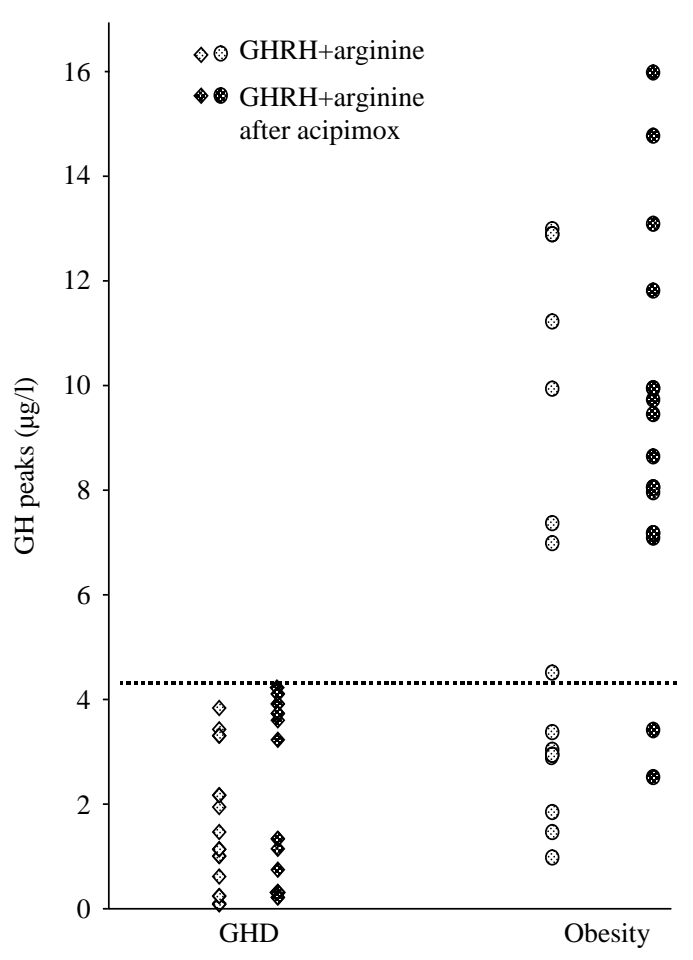

Figure $2 \mathrm{GH}$ peaks after GHRH + arginine with and without acipimox pretreatment in individual $\mathrm{GH}$-deficient and obese patients.

\section{Results}

The mean GH peak in response to GHRH+arginine was significantly lower in obese hypopituitary patients than in subjects with essential obesity $(1.63 \pm 1.37$ vs $5.99 \pm 4.38 \mu \mathrm{g} / \mathrm{l}, P<0.01$ respectively; Fig. 1). Acipimox pretreatment improved the $\mathrm{GH}$ response to the combined test in patients with essential obesity (mean $\mathrm{GH}$ peak from $5.99 \pm 4.38$ to $9.31 \pm 3.86 \mu \mathrm{g} / \mathrm{l}$, $P<0.05$ ), but not in hypopituitary subjects (mean GH peak from $1.63 \pm 1.37$ to $2.20 \pm 1.70 \mu \mathrm{g} / \mathrm{l}, P=\mathrm{NS}$ ). As a consequence, the mean absolute increase in GH peaks after acipimox was significantly higher in non-hypopituitary than in hypopituitary patients $(3.33 \pm 3.71 \mathrm{vs}$ $0.57 \pm 0.91 \mu \mathrm{g} / \mathrm{l}, P<0.05)$. Notably, in all hypopituitary patients, single $\mathrm{GH}$ peaks were below $4.2 \mu \mathrm{g} / \mathrm{l}$, the proposed cut-off value for the diagnosis of severe GHD in subjects with $\mathrm{BMI}>30 \mathrm{~kg} / \mathrm{m}^{2}(8)$. Out of 14 patients with essential obesity, 7 patients also displayed single $\mathrm{GH}$ peaks lower than $4.2 \mu \mathrm{g} / \mathrm{l}$ after $\mathrm{GHRH}+$ arginine (Fig. 2). In this subgroup of seven patients, acipimox premedication enhanced the response to the combined test, with a mean $\mathrm{GH}$ peak rising from $2.41 \pm 0.93$ to $7.76 \pm 3.51 \mu \mathrm{g} / \mathrm{l}(P<0.01$; Fig. 3). Conversely, the mean GH peak of the seven obese patients with single $\mathrm{GH}$ responses $>4.2 \mu \mathrm{g} / \mathrm{l}$ was not significantly affected by acipimox (from $9.57 \pm 3.28$ to 10.87 $\pm 3.79 \mu \mathrm{g} / \mathrm{l}, P=\mathrm{NS}$ ). 
When considering single subjects, acipimox pretreatment was unable to induce $\mathrm{GH}$ responses $>4.2 \mu \mathrm{g} / \mathrm{l}$ in any of the hypopituitary patients. Conversely, it caused a significant improvement in the somatotropin response of five out of the seven obese patients showing a GH peak lower than $4.2 \mu \mathrm{g} / \mathrm{l}$, while in the remaining two cases, no change in GH peak was observed (Figs 2 and 4).

Baseline circulating FFAs were superimposable in patients with essential obesity and in hypopituitary subjects $(0.73 \pm 0.18$ vs $0.84 \pm 0.42 \mathrm{mmol} / \mathrm{l}, P=\mathrm{NS}$ respectively). After acipimox administration, serum FFAs significantly fell in both groups (from 0.73 \pm 0.18 to $0.16 \pm 0.17 \mathrm{mmol} / \mathrm{l}, P<0.001$, in essential obesity, and from $0.84 \pm 0.42$ to $0.38 \pm 0.30 \mathrm{mmol} / \mathrm{l}$, $P<0.01$, in hypopituitarism) with comparable mean absolute decreases $(0.59 \pm 0.20$ vs $0.46 \pm 0.24 \mathrm{mmol} / \mathrm{l}$, $P=$ NS respectively). When considering the two subgroups of patients with essential obesity displaying $\mathrm{GH}$ responses to GHRH + arginine respectively lower and $>4.2 \mu \mathrm{g} / \mathrm{l}$, FFA values were superimposable under basal conditions and fell in a comparable manner after acipimox. In these two subsets of patients, BMI and serum insulin were also superimposable.

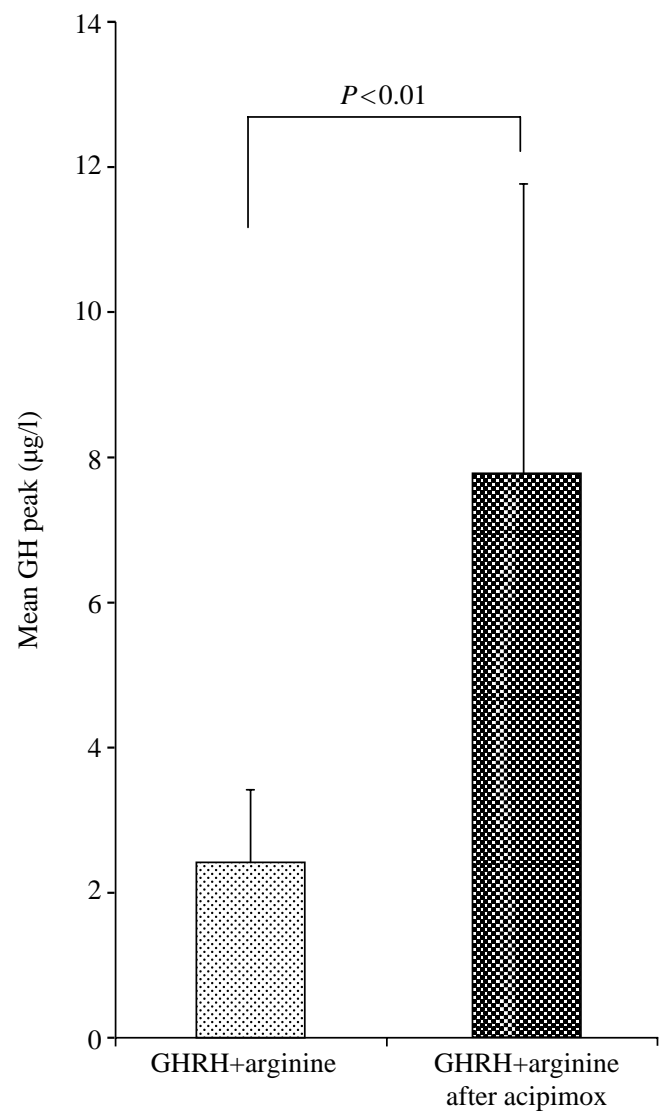

Figure 3 Improvement in mean GH peak after acipimox pretreatment in the subgroup of seven obese patients showing $\mathrm{GH}$ responses lower than $4.2 \mu \mathrm{g} / \mathrm{l}$ after $\mathrm{GHRH}+$ arginine.

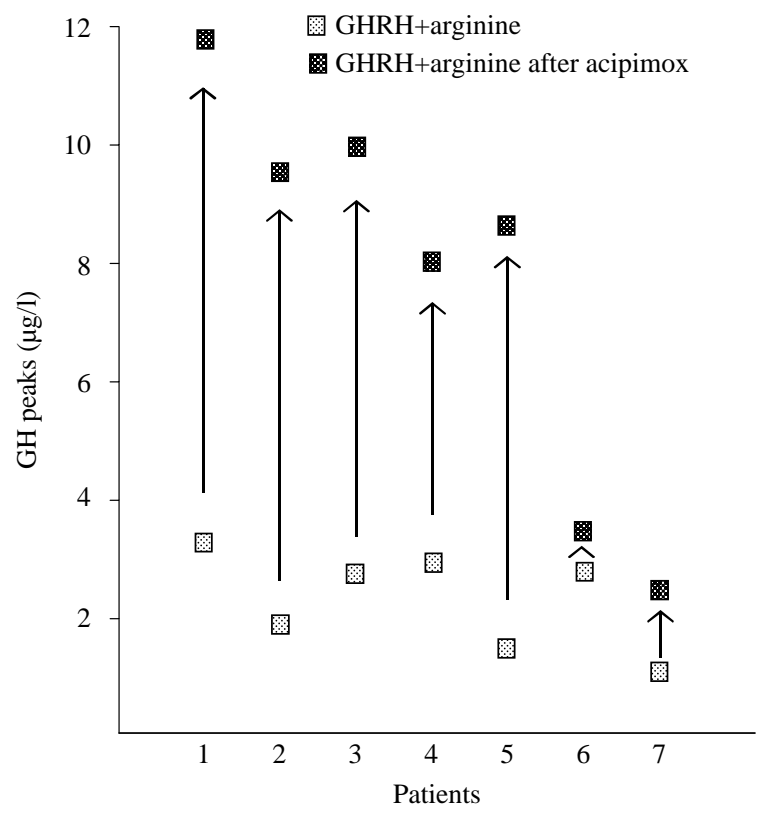

Figure 4 Acipimox-induced improvement in single GH peaks in the subgroup of seven obese patients with $\mathrm{GH}$ responses lower than $4.2 \mu \mathrm{g} / \mathrm{l}$ after $\mathrm{GHRH}+$ arginine.

All IGF1 SDS values were normal in both groups of subjects. In particular, mean IGF1 SDS was superimposable in non-hypopituitary and hypopituitary patients $(-0.66 \pm 0.81$ vs $-0.63 \pm 0.84, P=\mathrm{NS})$. Furthermore, in patients with essential obesity, mean IGF1 SDS values were comparable in subjects showing $\mathrm{GH}$ responses respectively greater and lower than $4.2 \mu \mathrm{g} / \mathrm{l}(-0.5 \pm 0.8$ vs $-0.7 \pm 0.7, P=\mathrm{NS})$.

No significant correlations were found between BMI values and GH peaks after both tests in patients with essential obesity and in hypopituitary subjects.

\section{Discussion}

Our study has demonstrated that the acute reduction of circulating FFA levels induced by acipimox increases the mean somatotropin response to GHRH + arginine in patients with essential obesity, whereas it has no effect in subjects with GHD. More important, in a relevant percentage of patients with essential obesity, the GH response to the combined test turned out to be lower than $4.2 \mu \mathrm{g} / \mathrm{l}$, i.e. the cut-off proposed by Corneli et al. (8) for the diagnosis of severe GHD in subjects with BMI $>30 \mathrm{~kg} / \mathrm{m}^{2}$ and accepted by several scientific societies (10). Interestingly, acipimox was particularly able to improve mean GHRH + arginine-induced somatotropin release in this peculiar subgroup of obese patients, while it was ineffective in those displaying better responses to the combined test. These results may appear at variance with those observed by Maccario et al. (13) in only six obese 
patients who, like seven of our patients, already displayed a significant $\mathrm{GH}$ rise after GHRH + arginine administration without acipimox. It appears from both our present experience and the literature (13) that in obese patients showing adequate, possibly maximal, GH rises after GHRH + arginine, acipimox premedication does not further improve these responses. We had the opportunity to compare this subgroup of obese patients with the subset comprising those characterized by the acipimox-induced improvement of an originally insufficient GH response to GHRH + arginine. The two subgroups displayed superimposable BMI values, as well as serum levels of FFAs and insulin; they also presented comparable FFA decreases after acipimox. Considering that this antilipolytic drug is known to strongly reduce serum insulin in obese patients (14) and that hyperinsulinemia might be involved in the hyposomatotropism of obesity (11), different reductions of insulin levels in our two subsets of patients might explain different GH behaviors. Unfortunately, we lack a sufficient number of insulin determinations following acipimox administration to establish comparisons with baseline in both groups.

In our hands, although with the limitations due to the relatively small number of patients studied, the GHRH + arginine test displayed, with a cut-off value of $4.2 \mu \mathrm{g} / \mathrm{l}$, a $100 \%$ sensitivity, while its specificity rose from 50 to $85.7 \%$ after acipimox premedication. However, the possibility that the two obese patients who failed to increase GH levels above $4.2 \mu \mathrm{g} / \mathrm{l}$ in the GHRH + arginine + acipimox test were really GH-deficient cannot be excluded, and this would clearly improve the specificity of the test.

The diagnosis of GHD in obese patients is complicated by the markedly reduced spontaneous and stimulated GH secretion that characterizes this clinical condition, and indeed overweight is the main confounding factor in the interpretation of the $\mathrm{GH}$ response to all provocative tests.

In obesity, a reduction in the half-life of $\mathrm{GH}$ as well as a significant decrease in the synthesis and secretion of the hormone has been reported $(11,15)$ with the net result of low plasma GH levels. The pathophysiology of this hyposomatotropism involves neuroendocrine and metabolic alterations. Among the former, dysregulation of GHRH, somatostatin, and ghrelin pathways has been demonstrated; among the latter, hyperinsulinemia and excess of circulating FFAs seem to play a major role.

The role of elevated FFAs in the GH hyposecretion of obesity has been investigated using the antilipolytic drug acipimox, whose acute and chronic administration effectively reduces circulating FFA levels. The improvement in the somatotropin response to GHRH+ pyridostigmine observed by Lee et al. (16) in obese subjects pretreated with acipimox suggested that elevated FFA levels and somatostatinergic hypertone might play a leading role.
In the experience of Cordido et al. (17), although unable to modify basal GH secretion, acipimox improved the hormonal responsiveness to pyridostigmine, GHRH, and GHRH + GHRP6, with a synergistic effect, confirming the role played by high FFAs. Comparable results were obtained by Pontiroli et al. (18) in a similar experimental setting. Prolonged acipimox administration, leading to sustained FFA suppression, has proved even more effective than the acute treatment in improving GH responses to pharmacological challenges $(13,19)$.

A few studies $(13,20)$ have evaluated the usefulness of combined administration of acipimox and GHRH for the diagnosis of GHD in obese adults, using the pharmacological blockade of lipolysis to refine the differential diagnosis between true GHD and the reversible somatotropin deficit secondary to obesity. However, according to the findings of Cordido et al. (21), GHRH + GHRP6 was superior to GHRH + acipimox in distinguishing the two situations.

None of these studies investigated the association of acipimox with GHRH + arginine, now considered the best alternative to ITT (the gold standard for the diagnosis of GHD in adults, but limited by contraindications) thanks to its reproducibility, reliability, safety profile, high sensitivity, and specificity. Moreover, GHRH + arginine is the only test for which BMI-dependent variability of $\mathrm{GH}$ responsiveness has been investigated $(8,9)$.

In our experience, half of the patients with essential obesity displayed a somatotropin response to the combined test lower than $4.2 \mu \mathrm{g} / \mathrm{l}$; thus, they would have been considered as affected by true GHD according to the current guidelines (6). On the contrary, the ability of acipimox to improve GH responsiveness in most of these patients (5/7) excluded the diagnosis of hypopituitarism. The two patients whose GH response was not improved by the antilipolytic drug were investigated for possible undiagnosed hypopituitarism. However, the remaining pituitary function was normal, and the sellar magnetic resonance imaging was negative in both cases. Furthermore, the acipimox-induced decrease in FFA levels was comparable with that observed in the other patients. Thus, the clinical significance of this finding in these two patients remains puzzling, and a replacement therapy with biosynthetic $\mathrm{GH}$ has to be taken into account.

In keeping with the limited number of patients examined, this study was not designed to define cut-off values for the somatotropin response to GHRH+ arginine+acipimox. On the other hand, our observations suggest that the current criterion for the diagnosis of GHD in obese patients, i.e. a GH peak lower than $4.2 \mu \mathrm{g} / \mathrm{l}$ in response to GHRH + arginine, may be misleading. Indeed, subjects affected by third degree obesity $\left(\mathrm{BMI}>40 \mathrm{~kg} / \mathrm{m}^{2}\right)$, like most of our patients, may be erroneously classified as really GH-deficient and started on an expensive unjustified 
treatment. Therefore, it appears that the current criteria for the diagnosis of GHD in obesity should be reconsidered in the light of further studies also taking into account different BMI groups.

If acipimox use in combination with GHRH+ arginine may be of help in defining GHD in selected doubtful cases, further studies on larger series of subjects are needed to allow the extensive use of this test as an additional tool in the diagnosis of GHD.

\section{Declaration of interest}

The authors declare that there is no conflict of interest that could be perceived as prejudicing the impartiality of the research reported.

\section{Funding}

This research did not receive any specific grant from any funding agency in the public, commercial, or not-for-profit sector.

\section{References}

1 De Boer H, Blok GJ \& van der Veen EA. Clinical aspects of growth hormone deficiency in adults. Endocrine Reviews 199516 63-86.

2 Rosen T \& Bengtsson BA. Premature mortality due to cardiovascular disease in hypopituitarism. Lancet 1990336 285-288.

3 Molitch ME, Clemmons DR, Malozowski S, Merriam GR, Shalet SM, Vance ML, the Endocrine Society's Clinical Guidelines Subcommittee \& Stephens PA. Evaluation and treatment of adult growth hormone deficiency: an Endocrine Society Clinical Practice guideline. Journal of Clinical Endocrinology and Metabolism 200691 1621-1634.

4 Carroll PV, Christ R, Bengtsson BA \& Carlsson L. Growth hormone deficiency in adulthood and the effects of growth hormone replacement: a review. Journal of Clinical Endocrinology and Metabolism $1998 \mathbf{8 3} 382-395$.

5 Growth Hormone Research Society (GRS): consensus guidelines for the diagnosis and treatment of adults with GH deficiency. Statement of the GRS workshop on adult GHD. Journal of Clinical Endocrinology and Metabolism 199883 379-381.

6 Maccario M, Gauna C, Procopio M, Di Vito L, Rossetto R, Oleandri SE, Grottoli S, Ganzaroli C, Aimaretti G \& Ghigo E. Assessment of GH/IGF-I axis in obesity by evaluation of IGF-I levels and the $\mathrm{GH}$ response to $\mathrm{GHRH}+$ arginine test. Journal of Endocrinological Investigation 199922 424-429.

7 Maccario M, Valetto MR, Savio P, Aimaretti G, Baffoni C, Procopio M, Grottoli S, Oleandri SE \& Arvat E. Maximal secretory capacity of somatotrope cells in obesity: comparison with $\mathrm{GH}$ deficiency. International Journal of Obesity and Related Metabolic Disorders 199721 27-32.

8 Corneli G, Di Somma C, Baldelli R, Rovere S, Gasco V, Croce CG, Grottoli S, Maccario M, Colao A, Lombardi G, Ghigo E, Camanni F \& Aimaretti G. The cut-off limits of the GH response to GH-releasing hormone-arginine test related to body mass index. European Journal of Endocrinology 2005153 257-264.

9 Colao A, Di Somma C, Savastano S, Rota F, Savanelli MC, Aimaretti G \& Lombardi G. A reappraisal of diagnosing GH deficiency in adults: role of gender, age, waist circumference, and body mass index. Journal of Clinical Endocrinology and Metabolism $2009944414-4422$.
10 Ho KK on behalf of the 2007 GH Deficiency Consensus Workshop Participants. Consensus guidelines for the diagnosis and treatment of adults with GH deficiency II: a statement of the GH Research Society in association with the European Society for Pediatric Endocrinology, Lawson Wilkins Society, European Society of Endocrinology, Japan Endocrine Society, and Endocrine Society of Australia. European Journal of Endocrinology 2007157 695-700.

11 Scacchi M, Pincelli AI \& Cavagnini F. Growth hormone in obesity. International Journal of Obesity 199923 260-271.

12 Brabant G, von zur Muhlen A, Wuster C, Ranke MB, Kratzsch J, Kiess W, Ketelslegers JM, Wilhelmsen L, Hulthen L, Saller B, Mattsson A, Wilde J, Schemer R, Kann P \& on behalf of the German KIMS Board. Serum insulin-like growth factor I reference values for an automated chemiluminescence immunoassay system: results from a multicenter study. Hormone Research 2003 $6053-60$.

13 Maccario M, Procopio M \& Grottoli S. Effects of acipimox, an antilipolytic drug, on the growth hormone $(\mathrm{GH})$ response to $\mathrm{GH}$-releasing hormone alone or combined with arginine in obesity. Metabolism $199645342-346$.

14 Worm D, Henriksen JE, Vaag A, Thye-Rønn P, Melander A \& Beck-Nielsen H. Pronounced blood glucose-lowering effect of the antilipolytic drug acipimox in noninsulin-dependent diabetes mellitus patients during a 3-day intensified treatment period. Journal of Clinical Endocrinology and Metabolism $1994 \mathbf{7 8}$ 717-721.

15 Veldhuis JD, Iranmanesh A, Ho KKY, Waters MJ, Johnson ML \& Lizarralde G. Dual defects in pulsatile growth hormone secretion and clearance subserve the hyposomatotropism of obesity in man. Journal of Clinical Endocrinology and Metabolism 199172 51-59.

16 Lee EJ, Nam SY, Kim KR, Lee HC \& Cho JH. Acipimox potentiates growth hormone $(\mathrm{GH})$ response to GH-releasing hormone with or without pyridostigmine by lowering serum free fatty acid in normal and obese subjects. Journal of Clinical Endocrinology and Metabolism $1995 \mathbf{8 0} 2495-2498$.

17 Cordido F, Peino R, Penalva A, Alvarez CV \& Casanueva FF. Impaired growth hormone secretion in obese subjects is partially reversed by acipimox-mediated plasma free fatty acid depression. Journal of Clinical Endocrinology and Metabolism $1996 \mathbf{8 1}$ 914-918.

18 Pontiroli AE, Manzoni MF, Malighetti ME \& Lanzi R. Restoration of growth hormone $(\mathrm{GH})$ response to GH-releasing hormone in elderly and obese subjects by acute pharmacological reduction of plasma free fatty acid. Journal of Clinical Endocrinology and Metabolism $1996 \mathbf{8 1} 3998-4001$.

19 Nam SY, Lee HC, Kim KR \& Cho JH. Long term administration of acipimox potentiates growth hormone response to growth hormone-releasing hormone by decreasing serum free fatty acid in obesity. Metabolism $1996 \mathbf{4 5} 594-597$.

20 Cordido F, Fernandez T, Martinez T \& Penalva A. Effect of acute pharmacological reduction of plasma free fatty acids on growth hormone $(\mathrm{GH})$ releasing hormone-induced $\mathrm{GH}$ secretion in obese adults with and without hypopituitarism. Journal of Clinical Endocrinology and Metabolism 199883 4350-4354.

21 Cordido F, Alvarez-Castro P, Isidro ML, Casanueva FF \& Dieguez C. Comparison between insulin tolerance test, growth hormone (GH)-releasing hormone (GHRH), GHRH plus acipimox and GHRH plus GH-releasing peptide 6 for the diagnosis of adult GH deficiency in normal subjects, obese and hypopituitary patients. European Journal of Endocrinology 2003149 117-122.

Received 8 April 2010

Accepted 11 May 2010 